\title{
Lobster Research in Norway
}

$\mathrm{D}^{\mathrm{R}}$ R. ALE DANNEVIG in a recent paper* gives a general review of the lobster industry and lobster culture in Norway. For about twenty years lobsters have been investigated at Flødevigen. Yearly grants have been made for this purpose, and much has been done in studying the lobster in all aspects, especially by fishery statistics, marking experiments and rearing the young to the bottom stage after which they are freed into the sea. The results of these researches have been published in various reports and journals, and here a collected view of the whole problem is given and discussed.

Beginning with the history of the fishery from early times to the present day, the author passes on to details of legislation and shows that there has been a big improvement in the fishery since a size limit and a close season were enforced.

Early researches on lobsters were made by Rathke, G. O. Sars, G. M. Dannevig, Appeløf and Sŭnd leading to the present author's work, which is chiefly concerned with the rearing of the young. The foundation of our knowledge of the life-history and development was laid down by G. O. Sars, who in 1875 described the post-embryonic development for the first time. The newly hatched larvæ he found in the well of a fishing boat and later collected them in the surface waters of the sea by means of a fine net. In this way he distinguished three larval stages and prophesied that the fourth would probably be on the bottom, which was later found to be true. Even in these early years, Sars advocated summer protection and inspection, both of which have now been in force for some time.

Lobsters were first artificially reared from the egg to the bottom stage by G. M. Dannevig, who showed that the young were very sensitive to salinity and, more especially, to temperature, and also found out the proper way to feed these young. Appellof did much in the way of biology and studied specially the growth of the lobster and instituted marking experiments. It was on the basis of his work that special rearing experiments were begun in 1912 by O. Sŭnd, who carried out systematic measurements of lobsters on various parts of the coast. Later the rearing experiments were continued by Alf Dannevig, and are still going on at Flødevigen.

It is shown that males are mature at a length of about $16 \mathrm{~cm}$. at Flødevigen and females at between about $21-23 \mathrm{~cm}$. The eggs are extruded in the summer and development takes about a year, during which time the female keeps the eggs under its abdomen attached to the pleopods. Hatching usually takes place in June or July according to the temperature of the water. A spawning lobster of $23 \mathrm{~cm}$. may have about five thousand eggs. The larval development through three free-swimming stages to the bottom stage takes about fourteen days with favourable conditions and normal summer temperature-about $16-18^{\circ} \mathrm{C}$. in the Skagerak.

The natural food of the youngest stages consists of small planktonic animals, but in captivity they

*Hummer og Hummerkultur. By Alf Dannevig. (Fiskeridirektorstets Skrifter. Serie Havundersøkelser. $\begin{aligned} & \text { Report on Norwegian } \\ & \text { Fishery and Marine Investigations, 4, No. 12. (Copenhagen: Director }\end{aligned}$ of Fisheries, 1936.) thrive on crab meat and ox liver. They seize almost anything but throw it away if not liked. In the rearing experiments in the Isle of Man which have been going on for some years, the larvæ are fed with fresh plankton in which copepods predominate, and they thrive on this. Adult lobsters are not naturally carrion eaters, although they will eat dead fish and crabs. Dannevig has observed that in Nature, seaurchins, chætopods and thin-shelled mussels take a prominent place as food and he has also found remains of fish. Little is eaten in cold weather, the appetite rising with temperature. No food is taken just before and during the period of shell casting, which takes place usually in late summer and autumn when the reserve food is consumed. During the first few days after casting, the lobster does not eat, but as the new shell hardens the appetite grows and soon is normal again. The best quality lobsters are those with a thick shell which has not been cast for some time; thus the best lobsters are usually those caught in the late winter and spring. In captivity, it is essential to feed the lobsters if they are to be in good condition for eating, otherwise they are watery. Temperature and food are of great importance with regard to shell casting, and lobster growth depends on the casting of the shell.

Growth measurements in captivity compare favourably with those in Nature obtained from marking experiments, and the reared lobster young at Flødevigen grow in much the same way as those reared at Port Erin, Isle of Man. The young at Flødevigen reach a length of about $30 \mathrm{~mm}$. in the first growth period and about $60 \mathrm{~mm}$. in a year, the shell casting, practically speaking, being limited to the time when the temperature is above $10^{\circ} \mathrm{C}$.

Marking experiments have shown that there is little sign of wandering far, although the lobsters come into shallow water when the water is warm and go down into the deeper water when it becomes cold, or in stormy weather. On most of the Norwegian coast the wandering is probably limited to about a hundred metres in a horizontal plane. There may then be said to be a stationary stock and, usually, about 44 per cent of the marked lobsters are caught again the year after marking. For example, a hundred lobsters, 19-20 cm., were released in the autumn and 44 were taken again the next autumn, the average size being $22 \mathrm{~cm}$.

The present minimum size is $21 \mathrm{~cm}$, and since it is known that hens are normally not ripe until 22-24 $\mathrm{cm}$, it is clear that raising the minimum size to $22 \mathrm{~cm}$. would save many which will breed the next year, especially as the greater part of the fishermen's present catches consists of those of less than $22 \mathrm{~cm}$. This would also be of advantage eventually to the fishermen, for the catches though smaller would be more valuable. It is calculated that, if the minimum size is raised a centimetre, after two years there will be an increased lobster stock, and this with no lasting expense to the fishery.

Since 1879 there has been a protection period to prevent fishing of lobsters which have just cast their shell. This is from July 15 until the first weekday after September 15, varying slightly in different 
districts. An earlier protection time in spring would save many breeding lobsters, and extension to later in autumn would bring with it a better quality of fish.

The breeding experiments at Flødevigen are carried on in view of the fact that by increasing the number of young by enclosing a mother lobster, hatching the eggs in captivity and rearing the young to the bottom stage, an increase of lobster stock will be effected, for in this way the larval stages which are the most exposed to dangers are protected for the most susceptible time of their life. The lobsterlings when they have attained the bottom stage are set free into the sea. A technique has now been evolved which is very sure, and one can reckon on an output of 20-40 per cent. It is now possible to bring lobster young from the egg to the bottom stage in so great numbers that it is undoubtedly valuable in increasing the stock. This technique has been described in Dannevig's former paper "The Rearing of Lobster Larvæ at Flødevigen" (1928). The technique being established, it is now only a question of how cheaply the whole of the rearing and transport can be effected. There is every ground for believing that it is possible to bring working expenses of production down to a fractional part of the present amount. The plans for the immediate future include still further research in those areas where the young are released. So far, the rearing experiments have prospered. Important results should follow these successes.

\section{Petroleum and Petroleum Products}

$\mathrm{T}$ HE group of papers on conservation of petroleum and natural gas given at the third World Power Conference forms the subject of a report by $\mathrm{H}$. C. Fowler (Section IV, Paper No. 12). Mr. Fowler stressed the principle enunciated by Sir John Cadman that petroleum should not be produced without adequate need, having regard to the vital part played by crude petroleum in the life of civilized communities to-day, and the view held by technicians that resources of crude petroleum are not unlimited. The problem of conservation presents a different aspect in each oil-producing country, and it is difficult to assess it from the point of view of world resources. In the case of the United States of America, the problem is unique and the ultimate policy adopted there will probably have a greater influence on the world petroleum industry as a whole than that of all other oil-producing countries combined.

Before effective measures for world conservation can be adopted, however, there are certain preliminary investigations to be made. The extent and character of waste production in countries having relatively large portions of known oil resources should be determined and note taken of methods employed to conserve resources under specific conditions. In those countries which depend chiefly on imported supplies of oil, the problem should be regarded from the point of view of conservation of utilization. Further, organization of the industry in different countries should be surveyed from the point of view of the effect of property laws, State regulations, etc. Finally, the uses of petroleum should in every case be justified or otherwise, and decisions on this point taken only with full cognisance of all possible sub. stitutes for petroleum and a knowledge of their specific uses. These and other economic factors which are bound to affect utilization and conservation of petroleum should be carefully weighed before judgment is passed on the whole problem of how best to use or conserve this commodity, which now seems indispensable to modern industrial life, but is at the same time believed to be capable of exhaustion.

In his general report (Section II, Paper No. 6) on papers submitted at the Conference on the organization of the production, transportation and distribution of natural and manufactured gas, E. R. Weaver directed attention to the marked contrast between European and American practices within the gas industry. The contrast is chiefly attributable to the greater abundance and variety of fuels obtain. able in America, and to different legal and financial factors within the industry. Moreover, in practically every European country, distribution of adequate gas supplies is undertaken by public bodies, whereas in the United States of America public interest is for the most part not represented on the boards and councils of gas concerns. Large holding companies, therefore, compete with each other for areas of supply and are not responsible for their policies to any higher authority. This fact cannot be said to further ultimate national conservation of this commodity in America.

In the case of European countries, a strikingly similar development of the gas industry appears to have taken place in each of them, and such differences as exist are rather differences in stages of development than fundamental dissimilarities. Germany is at present pursuing an advanced policy of consolida. tion, the professed ideal being delivery of gas to every station at every moment as economically as possible, and also at the same time withdrawal from each producing unit of an allotted quota. To achieve this, not only daily but also hourly load of every pipe has to be calculated and attention given to weather reports and other factors likely to influence gas sales. The question now being debated by technicians is whether fundamental conditions exist in other European countries which will prohibit a similar national programme of gas economy to that aimed at by Germany.

E. B. Swanson gave a general report (Section II, Paper No. 5) on papers in connexion with present-day organization of the petroleum industry. The industry may be said to comprise five structural components: exploration, production, transportation, manufacturing and distribution. The degree of economic stability attainable by an individual country or company is dependent largely upon the extent to which it is possible for it to enter into all five branches of the industry's activities. Papers descriptive of the organization of the petroleum industry in the Argentine, Austria, Canada, China, France, Germany, Great Britain, Hungary, Poland and the United States, substantiate this fact, and at the same time facilitate classification of these countries into four categories : producer; producer-refiner-marketer ; purchaser-refiner-marketer ; and purchaser-marketer. 